\title{
Building power through crisis
}

\author{
Saru Jayaraman ${ }^{1}$
}

Accepted: 25 April 2020 / Published online: 16 June 2020

(c) Springer Nature B.V. 2020

COVID 19 has both revealed the deep structural inequities of the service sector and created a tremendous opportunity to organize both workers and employers for the change we always needed. There is no going back-we can only go forward together, and reimagine an industry in which all thrive.

Prior to the pandemic, there were more than 13 million restaurant workers and nearly 6 million tipped workers across the United States who struggled with a federal subminimum wage of just $\$ 2.13$ an hour. Seventy percent of tipped workers are women, disproportionately women of color, who work in nail and hair salons and casual restaurants like IHOP and Denny's, live in poverty at three times the rate of the rest of the U.S. workforce, and suffer from the worst sexual harassment of any industry because they are forced to tolerate inappropriate customer behavior in order to feed their families in tips. ${ }^{1}$

Seven states-CA, OR, WA, AK, MN, NV, and MT - have rejected this legacy of slavery and pay One Fair Wage - a full minimum wage with tips on top. These states have comparable or higher restaurant sales per capita, job growth among tipped workers and the restaurant industry overall, and tipping averages than the 43 states with lower wages for tipped workers, and half the rate of sexual harassment in the restaurant industry. ${ }^{2}$ One Fair Wage, the organization I lead, has been fighting to ensure that the nation follows the leadership of these seven states.

The subminimum wage for tipped workers resulted in a horrific experience for millions of tipped workers as a result of the COVID-19 economic shutdown. We estimate that between 4.5 and 9 million restaurant and other tipped workers have already lost their jobs. Most are ineligible for unemployment insurance; hundreds of tipped workers have reported to us that they are being denied unemployment

This article is part of the Topical Collection: Agriculture, Food \& Covid-19.

Saru Jayaraman

saru@onefairwage.org

1 New York, USA insurance because their subminimum wage plus tips is so low it does not meet the minimum threshhold to obtain unemployment insurance. In other words, these workers are being penalized because their employers paid them too little.

We launched the One Fair Wage Emergency Fund on Monday, March 16 to provide cash relief to thousands of low-wage service workers; the Fund has exceeded 150,000 worker applicants in the last month. We have built an army of almost 1000 volunteers who are calling each worker to screen them for need, organize them into One Fair Wage, and register them to vote.

We have now raised over $\$ 20$ million to date to hand out relief to thousands of workers; we are also providing individual counseling to workers with regard to their unemployment benefits and finances. More importantly, we are organizing these thousands of workers into large national and state tele-town halls and virtual rallies with Congressmembers, governors, and other state legislators to allow them to raise their voices and make demands. It is a new and unique moment in oragnizing - thousands of workers are attending these virtual events and demanding change with a fervor we've rarely seen.

But we aren't stopping with just organizing workers-the extraordinary moment calls for more. In fact, several restaurant owners who previously opposed or were hesitant about One Fair Wage are now willing to work with us to commit to One Fair Wage and increased equity next year. For some,

$\overline{1}$ Restaurant Opportunities Centers United, Family Values @ work, et al., Tipped Over the Edge: Gender Inequity in the Restaurant Industry (Feb. 2012) available at: https://rocunited.org/wpcontent/uploads/2012/02/ROC_GenderInequity_F1-1.pdf; While only 7 percent of American women work in the restaurant industry, more than a third (37 percent) of all sexual harassment claims to the Equal Employment Opportunity Commission come from the restaurant industry. See: Tahmincioglu, E. (2011, November 1). Sexual claims common in pressure-cooker restaurant world. Retrieved September 13, 2014, from https://business.nbcnews.com/_ news/2011/11/01/8565198-sexualclaims-common-in-pressure-cooke r-restaurant-world

2 Bureau of Labor Statistics, "Quarterly Census of Employment and Wages 2015." Accessed August 9, 2016. Available at: www.bls.gov/ cew/. Bureau of Labor Statistics, "2012 Economic Census.” Accessed August 9, 2016. Available at www.census.gov/econ/. 
their eyes have been opened to the unsustainability of the system; for others, the moment has allowed them to break free from an old business model that they could not see how to change. Some are even working with us to design model restaurants of the future.

The pandemic is both the gravest crisis in the service sector's history in the United States and also the greatest moment for transformation - for building power among workers and change among employers toward a sustainable future of collective prosperity.

Publisher's Note Springer Nature remains neutral with regard to jurisdictional claims in published maps and institutional affiliations.

Saru Jayaraman is the President of One Fair Wage, the Director of the Food Labor Research Center at UC Berkeley, and the author of Behind the Kitchen Door and Forked: A New Standard for American Dining. 